\title{
nature
}

Vol 440 | Issue no. 7084 | 30 March 2006

\section{Brown's budget briefing}

\section{A more cohesive biomedical research agency and simpler arrangements for measuring university performance feature in Britain's 2006 budget.}

n n most years, in most countries, the only element in a finance minister's budget statement that grabs researchers' immediate attention is the measly percentage increase that their funding agency has managed to prise out of government for the coming year.

But when Gordon Brown, the British chancellor of the exchequer, stood up to deliver his budget statement on $23 \mathrm{March}$, he had some interesting things to say to scientists. The statement proposed two reform initiatives that most researchers will welcome, if they are implemented with care.

Thanks in part to Brown's conviction that research is key to economic growth, the Labour government has upped annual science spending by about $70 \%$ since it came to power in 1997 , to more than $£ 2.5$ billion (US $\$ 4.4$ billion). There were no spending increases this time. But Brown, who is expected to succeed Tony Blair as prime minister at some point in the next two years, has clearly been giving some thought to how British research could be strengthened.

The most significant planned change is a shake-up of biomedical research, to bring science and clinical trials under one roof. At present, they are divided between the Medical Research Council (MRC), which supports biomedical science, and the National Health Service (NHS), which runs clinical trials and other healthcare research through its network of local health trusts.

\section{Two into one}

The NHS research and development budget is $£ 750$ million, around $£ 200$ million more than that of the MRC, but NHS research has a far lower profile, both scientifically and publicly. One reason is that the money is spent through the local trusts, which also provide day-today healthcare. In this situation, it is perhaps inevitable that some resources theoretically allocated to long-term research end up diverted to immediate healthcare needs.

Brown aims to end this split. A merger of the NHS's research with that of the MRC will create a new, as yet unnamed agency, which the Treasury says will receive "at least" $\mathrm{E} 1$ billion in funding each year. The agency will support all biomedical research, from basic studies to clinical trials, in the manner of the US National Institutes of Health. Senior researchers have welcomed the plan. Even if the annual budget is slightly less than the total budget of the two current operations, it will still represent a significant increase in biomedical research funding, as all of the money will now actually be spent on research.

The merger will be complex to implement, however. The budget statement says that the new arrangement will be jointly administered by the Department of Health, which runs the NHS, and the Department of Trade and Industry (DTI), which currently oversees the MRC and Britain's other research councils. But the research councils enjoy arms-length relationships with the DTI that prevent political meddling and protect their scientific reputations. It is vital that the newbody has a similar arrangement to protect it from political interference by ministers at either of the departments that will be responsible. The government has yet to clarify how this will be achieved.

Researchers will also be glad to see the back of the Research Assessment Exercise, a mechanism to measure university departments' performance, whose expiry after a final outing in 2008 was confirmed in Brown's budget statement. The exercise, which has taken place every seven years or so since 1985 , has helped the government to determine the levels of fixed funding, on top of research grants, for Britain's universities. But it is vastly time-consuming for overseers and overseen alike, and its usefulness as a management tool has been gradually waning.

\section{Measure for measure}

Brown is proposing to replace the Research Assessment Exercise with a system that rewards departments on the basis of performance metrics. One metric highlighted in the budget statement, external research income, seems a reasonable basis for departmental funding, as this income correlates very well with the peer review that was done in the assessment exercise.

But other types of research metrics - however attractive they might look to those who make funding choices - should be handled with great care. Citation statistics, for example, are a notoriously unreliable and inconstant guide to research quality. The top research agen-
"It is vital that the new biomedical-research body hasan arrangement to protect it from political interference by ministers." cies in the United States have successfully resisted periodic drives by bureaucrats to use them to measure the worth of the science that they should be supporting.

One way forward for the UK government would be to let reliable metrics, such as total external research income, replace much of the Research Assessment Exercise process, while retaining a slimmeddown version of the subject panels that currently oversee each discipline. All disciplines could then base their evaluations on research income, but the subject panels could tweak the process to reflect the needs of their particular fields of study. For example, they might choose to reward academics working on valuable long-term projects, such as the collection of environmental or astronomical data sets, the importance of which is not reflected in the metrics.

The government will now consult interested parties on both the biomedical and research-assessment proposals, each of which holds considerable potential. If the scientific community has a voice in how the proposals are implemented, that potential will be realized. There might not be new money on the table in this particular budget, but it contains ample opportunity to build a better environment for science in Britain. 